\title{
HÊGEMONÍA: HEGEMONY, CLASSICAL AND MODERN ${ }^{1}$
}

\author{
David Wilkinson \\ Department of Political Science \\ University of California - Los Angeles \\ dow@ucla.edu
}

\begin{abstract}
"Hegemony" is a term from the vocabulary of classical Greek history which was deliberately revived in the $19^{\text {th }}$ century to describe a modern phenomenon. In its classical context, the clear denotation of "hegemony" is a military-political hierarchy, not one of wealth or cultural prestige; although both economic and cultural resources could serve to advance military-political hegemony, they were not at all of the essence. Hegemonic relations were conscious, and based upon complex motives and capacities. Individuals, peoples and states could desire, seek, struggle for, get, keep, lose and regain hegemony. Hegemony was sought or exercised over nations, over territories, over the land or the sea, or over tôn holon, "the whole"; but "territories" turn out to be the states and nations thereon, "the land" and "the sea" actually meant "the mainland states" and "the island states," and tôn holon was the world system, the whole system of interacting states. Hegemonic power relationships in the classical style are alive and well today; far from being time-bound, place-bound or culture-bound, hegemony in the classical sense is a transhistorical and transcultural fact that merits comparativecivilizational and comparative-world-systems study. While bilateral, alliance, and regional hegemonies are far more frequent both today and in the past, the most useful hegemony for study in a comparative civilizations/world systems context is systemwide hegemony: a unipolar influence structure that falls short of universal empire.
\end{abstract}

\section{INTRODUCTION}

Hegemonie (grch.), eigentlich Oberbefehl oder Obergewalt, nannte man in Griechenland namentlich die diplomatische und militaerische Fuehrung, die einem einzelnen Staate wegen seiner Machtfuelle, Tapferkeit und Kriegserfahrung seiner Buerger von einer Anzahl anderer Gemeinden eingeraeumt wurde. Zuerst trat Sparta, nachdem es zeit der Mitte des 6. Jahrh. v. Chr. der Vorort der peloponnes. Staaten geworden war, zur Zeit der

${ }^{1}$ Direct all correspondence to: David Wilkinson, Department of Political Science, University of California - Los Angeles, PO Box 90095-15472, Los Angeles, CA, 90095. 
Perserkriege an die Spitze von Hellas, indem damals die meisten griech. Staaten sein Fuehrerschaft sich unterordneten. Doch entstanden bald Spaltungen in dieser Verbindung. Sparta geriet seit 461 in Konflikt mit dem seemaechtigen Athen, welches selbst seit 476 an der Spitze eines grossen Inselbundes stand, und nun den Spartanern ueberall als ebenbuertige Macht die Spitze bot. Erst als die Macht Athens im Peloponnesischen kriege gebrochen war (404), konnten die Spartaner ihr frueheres uebergewicht wiedererlangen. Unter Epaminondas' fuehrung machte hernach Theben, welches Sparta in der Schlacht bei Leuktra (371 v. Chr.) demuetigte, eine Zeit lang mit Erfolg den Versuch, die H. an sich zu ziehen. Nach Epaminondas' Tode riss dann bei dem unaufhoerlichen inner Hader der Griechen Koenig Philipp von Macedonien als Sieger in der Schlacht bei Chaeronea (338 v. Chr.) die H. an sich.

Hegemony (Greek), literally, supreme command or supremacy, in Greece in particular designating the diplomatic and military control which was granted to an individual state because of the authority, bravery and war experience of its citizens by a number of other states. Sparta, having since the mid-6th century BC attained the first place among the Peloponnesian states, first reached the pinnacle of Hellas at the time of the Persian Wars, through most of the Greek states' subordinating themselves to its leadership at that time. But divisions soon developed in this connection. From 461, Sparta clashed with Athens, powerful at sea, which itself since 476 had headed a large island-league, and now offered its leadership everywhere, as a power equal to Sparta. Only after the power of Athens was broken in the Peloponnesian War (404) could the Spartans regain their earlier ascendancy. Afterwards, Thebes, under Epaminondas' guidance, which humiliated Sparta in the battle of Leuctra $(371 \mathrm{BC})$, tried to acquire the Hegemony, with success--for a while. Then after Epaminondas ' death, by reason of the incessant internal strife of the Greeks, King Philip of Macedon, as victor in the battle of Chaeronea (338 BC), seized the Hegemony (Allgemeine deutsche Real-Encyklopaedie fuer die gebildeten Staende, 1824, s.v. Hegemonie).

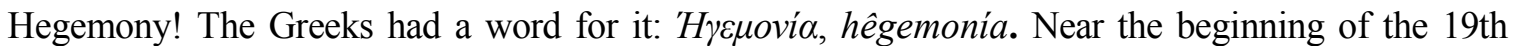
century, the Germans did too: Hegemonie. Continental classical scholars revived the ancient study of hegemony: landmark scholarly works were the 3 volume study of the rise and fall of Spartan "Hegemonie" by J.C.F. Manso (1800-1805) and the Dutch historian-politician Groen van Prinsterer's (1821) discussion of the "hegemonia" of Athens. The concept, directly appropriated with the classical meaning and references, but rendered into the appropriate vernacular, soon entered German popular encyclopedias and "Conversations-Lexica" such as those of F.A. Brockhaus (Allgemeine deutsche Real-Encyklopaedie fuer die gebildeten Staende, 1824) or H.A. Pierer (1840-1846), where it found enduring lodgement.

Indeed, the Greeks had so many words for or about hegemony that, when we look at the classics, we can hardly avoid the conclusions that hegemony is more than simply an ancient concept: it is an ancient subject of learning, well developed over centuries, and one which deserves to be examined in its own context in evaluating hegemonic theory in the current context, and in the comparative study of civilizations and world systems. What, then, do the Greeks have to say about 
hegemony, and its associated ideas? Quite a bit, in fact, and the topic is worth tracing even to its archaic roots.

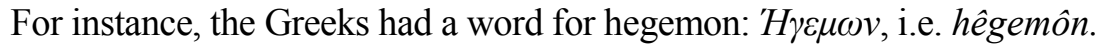

\section{THE HEGEMON IN HOMER}

The term hêgemôn, and some of its associates, can be found in Homer's Iliad. What is today called the "Catalogue of Ships" in the Iliad (2: 494-759) is labeled in the text itself $(2.487,2.760)$ as a list of the hêgemones Danaôn, giving the personal names of the headmen of 29 allied forces, which had converged upon Troy in more than a thousand ships--such names as Ajax, Diomedes, Agamemnon, Menelaus, Nestor, Odysseus, Idomeneus, Achilles, and dozens of others. In translation, the hêgemones become, variously, "captains" (1924 [Murray]: I:87; 1950 [Lang, Leaf and Meyers]: 33; 1997 [Lombardo]: 35), "chiefs" (1942 [Butler]: 33), "leaders" (2002 [Johnston]: iliad2, line 565), "lords" (1992: [Fitzgerald]: 51), and those "Who of the Greeks at Troy commanded men" (1844 [Hobbes]: 22). In action, the hêgemones give orders, lead others into combat, and take the forefront in battle. While none of the translations is wrong, I would incline to say that the best English rendering of Homeric hêgemôn is "commander."

While classical Greek adds other meanings for hêgemôn, the most frequent application of the term remains Homeric: it denotes an individual holding a military command, frequently also a political power-holder, king or emperor (Liddell and Scott 1968, s.v. hêgemôn).

\section{GREEK HÊGE- TERMS WITHOUT ENGLISH DESCENDANTS}

A further and substantial complex of Greek words deriving from the root hêge- refers to leadership, guidance, governance, and command, especially in war. Some members of the complex have not made their way into English: e.g. hêgemoneuô (lead the way, lead in war, rule, command, govern), as in the Iliad (2.816).

Trôsi men hêgemoneue megas koruthaiolos Hektôr Priamidês...

"The Trojans were led by (hêgemoneue) great Hector of the flashing helm, the son of Priam.... " (1924 [Murray]: I:111; "led" also in translations of 1844 [Hobbes]: 28, 1967 [Lombardo]: 47, and 1992 [Fitzgerald]: 62); "great Hector of the glancing helm was leader" (1950 [Lang, Leaf and Meyers]: 42); "Priam's son, great Hector of the gleaming helmet, commanded (hêgemoneue) the Trojans...."(1942 [Butler]: 40).

Like hêgemoneuô, hêgemoneus (governor), hêgemoneô (have authority), hêgemonis (imperial), hêgeomai (go before, lead the way, lead or command in war, rule, have dominion), hêgêsis (command), and hêgêtôr (leader, commander, chief) have also left no English descendants. (For each of these terms, see Liddell and Scott,1968, s.v. id.) But the case of hêgemonia is quite other. From it derives the enormously influential English term "hegemony." (One cognate term, "hêgemonikos," has also revived, as "hegemonic"). 
HEGEMONY, CLASSICAL AND MODERN 122

\section{HÊGEMONÍA AND "HEGEMONY"}

Hêgemonía has a flourishing modern descent: not just English "hegemony" and German "Hegemonie" but also "hegemonía" (Spanish), "egemonia" (Italian), and "hégémonie" (French). Why this progeny? The modern writers recognized that the classical concept of hêgemonia had contemporary relevance.

To the Greek writers, hêgemonía might imply no more than being a guide, going first, or setting an example; but more often it carried a weightier meaning--the authority or rule of a dynasty or nation, or of a general or officer; political leadership, political supremacy, chief command, imperium (Liddell and Scott, 1968 s.v. hêgemonía). It is the latter sense which was revived in the 19th century. The largest portion of the entry for hêgemonia in the "middle Liddell" Intermediate Greek-English Lexicon is the most concise and relevant reference: "hêgemonia...[II.2] the hegemony or sovereignty of one state over a number of subordinates, as of Athens in Attica, Thebes in Boeotia--the hegemony of Greece was wrested from Sparta by Athens; and the Peloponn[esian] war was a struggle for this hegemony." (Emphasis in original.)

The 19th century classicists recognized contemporary state-subordination phenomena that resembled the subordinations of classical history. The dominance of Holland within the confederate "Republic of the Seven United Provinces" (1581-1795), the dominance of Revolutionary and Napoleonic France over dozens of client republics, duchies and kingdoms, notably the "Confederation of the Rhine" (1806-1813), the dominance of Austria in the "German Confederation" (1815-1866), and, later, the dominance of Prussia in the "North German Confederation" (1866-1871) provided a striking set of current analogues. Accordingly, the English term "hegemony," like its cognates in other Western languages, deriving from an extension of classical studies to modern history, was quite consciously made close in its meaning to the Greek original: "Leadership, predominance, preponderance; esp. the leadership or predominant authority of one state of a confederacy or union over the others: originally used in reference to the states of ancient Greece, whence transferred to the German states, and in other modern applications" (Oxford English Dictionary 1933, s.v. hegemony).

This suggests that an examination of the ways in which the Greek historians used the term hêgemonía (and its cognates), and of how the hegemonies they observed rose, continued and fell, might be of more than merely antiquarian interest. The abstract concept hêgemonía is classical rather than Homeric, and occurs most frequently in the works, not of poets, but of historians and politicians--most frequently in Diodorus Siculus, Flavius Josephus, Appian, Polybius and Isocrates. Let us undertake an examination of classical "hegemony."

Leaving aside the many references to the personal "hegemonies" of monarchs and commanders (Josephus, for instance, is concerned especially with the "hegemonic" ambitions of would-be Roman emperors), the classical writers investigated the state "hegemonies" or struggles for hegemony of Assyrians, Medes, and Persians; of Syracusans, Carthaginians and Romans; and, especially, of Spartans, Athenians, Thebans and Macedonians in the 5th and 4th centuries BC.

\section{TRANSLATING HÊGEMONÍA}

The various English translations given to the classical Greek hêgemonia offer a constellation of interconnected concepts. Some translators - Strabo's translator H.L. Jones (1924), for instance - 
solve the problem by simply choosing "hegemony," but most, interestingly, choose one or another of a collection of not-quite-synonyms. These more nuanced renditions seem worth reviewing, and perhaps evaluating. The hêgemonía that hegemonizers sought, and hegemons achieved, has been variously translated as power, leadership, command, supremacy, dominance, dominion, lordship, sovereignty, and empire.

Hegemony means "power": in the Second Punic War, Scipio "crushed the Carthaginian power [tên hêgemonian Karchêdonious]" (Appian, The Foreign Wars: The Punic Wars, 1.2); "Scipio...humbled the Carthaginian power [ho Karchêdonious...tên hêgemonían]" (Appian, The Foreign Wars: The Syrian Wars, 2.9).

Hegemony means "leadership": the Scythians "originally possessed little territory, but later, as they gradually increased in power, they seized much territory by reason of their deeds of might and their bravery and advanced their nation to great leadership [eis megálên hêgemonian]" (Diodorus, 2.43.1). The legendary Athenian hero-king Theseus "accomplished ... the incorporation of the demes, which were small in size but many in number, into the city of Athens; ... from that time on the Athenians were filled with pride by reason of the importance of their state and aspired to the leadership of the Greeks [tês tôn Hellênôn hêgemonías]" (Diodorus, 4.61.9). When Xerxes the Persian invaded European Greece, the Athenians, to avert quarrels among the Greek resistance, waived their claim to command at sea, "seeing that if they quarrelled over the leadership [tês hegemoniês], Hellas must perish" (Herodotus, 8.3.1).

Hegemony means "command": before Xerxes' invasion of Greece, the allied Greek resistance asked Argos to join. The Argives replied that they would do so if they were awarded command of half the allied forces, although by right they should have had command [hêgemoniên] of the whole (Herodotus 7.148.4). When Gelon of Syracuse, whose power "was said to be very great, surpassing by far any power in Hellas," offered the Greek envoys an immense force with which to resist Persia, on condition of his being made "general and leader," the Spartan envoy indignantly denounced the idea that the Spartans should be "bereft of their command [tên hêgemoniên]" of the Greeks by a mere Syracusan (Herodotus, 7.145, 158-159). Command went to the Spartans; but the Spartan king Pausanias led the Greek alliance in an overbearing way, and, despite the allied victory at Plataea, the Athenians "made a pretext of Pausanias' highhandedness and took the command [tên hêgemoniên] away from the Lacedaemonians" (Herodotus, 8.3.2).

Hegemony means "supremacy": the Athenian general Cimon led an expedition to Cyprus (450-449 BC) with the objective of the "dissolution of the [Persian] King's entire supremacy [holês ... tês basileôs hêgemonías]" (Plutarch, "Cimon," 18.5). Euphemus, the Athenian ambassador to Camarina in the Sicilian Expedition of 415 BC, boasted that "after the Persian wars we acquired a fleet and rid ourselves of the rule and supremacy [arkhês kai hêgemonias] of the Lacedaemonians" (Thucydides, 6.82.2-3). After their defeat at Leuctra by Thebes, the Lacedaemonians "were never able to regain the supremacy over the Greeks [tên tôn Hellênôn hêgemonian] which they once possessed" (Strabo, Geography, trans. Jones, 9.2.39). In 314 BC Italy found "the Samnites, fighting bitterly against the Romans for supremacy [tês hêgemonías] in a struggle lasting many years" (Diodorus, 19.72.3). Scipio urged Rome to make a peace treaty with Carthage after the Second Punic War because "he considered it a sufficient success for Rome to have taken the supremacy [tên hêgemonian] away from Carthage" (Appian, The Foreign Wars: The Punic Wars, 9.65). 
Hegemony means "dominance": "in this present Book we shall set forth the events which took place in Asia in the ancient period, beginning with the time when the Assyrians were the dominant power [tês tôn Assuriôn hêgemonías]" (Diodorus, 2.1.3). Themistocles the Athenian "had recourse to many ... ambitious undertakings which would serve to increase the dominant position [hêgemonías]" of Athens (Diodorus, 11.41.2).

Hegemony means "dominion": "Thus was the dominion of the Romans [tên Rhômaiôn hêgemonian] divided by the triumvirate among themselves" (Appian, The Civil Wars, 4.1.3). The Romans prepared Italy "as a centre from whence to enforce their universal dominion [tên sumpasan hêgemonían] " (Strabo, Geography, trans. Hamilton and Falconer, 6.4.2).

Hegemony means "lordship": after Cyrus the Persian overthrew the Mede Astyages son of Cyaxares, he heard, but deprecated, a petition from his nobles to take advantage of the fact that "Zeus grants lordship [hêgemoniên] to the Persian people," by resettling the Persians in some softer and more fertile land (Herodotus 9.122.2).

Hegemony means "sovereignty": after Cyrus destroyed the "sovereignty [hêgemoniê]" of Astyages the Mede (Herodotus, 1.46.1), his successor Cambyses, on his deathbed, charged the Persian nobles "not to suffer the sovereignty [tên hêgemoniên] to fall again into Median hands" (Herodotus, 3.65.6).

Hegemony means "empire": under (the legendary and feckless last Assyrian emperor) Sardanapallus "the Empire of the Assyrians [hê tôn Assuriôn hêgemonía] fell to the Medes" (Diodorus, 2.21.8). Cyaxares, their king, "was the first to try to attach to himself the neighboring peoples and became for the Medes the founder of their universal empire [tês tôn holôn hêgemonías]" (Diodorus, 2.32.3). Cyrus "transferred the Empire [tên hêgemonian] of the Medes to the Persians" (Diodorus, 2.33.6) and founded "the Persian Empire [tês Persôn hêgemonías]" (Diodorus, 2.22.3); Julius Caesar "advanced the Roman Empire [tên hêgemonían tês Rômês] as far as the British Isles" (Diodorus, 1.4.7).

Power, leadership, command, supremacy, dominance, dominion, lordship, sovereignty, empire: classical hêgemonia sits somewhere in their company. Can its nature be further specified than by such synonyms alone?

\section{THE CHARACTER OF HEGEMONY}

As the diversity of its translation-terms may suggest, the classical hegemonic relationship could have any of several different characters. Hegemony could be accepted willingly or unwillingly. "The Thessalians, Phocians, Aetolians, and all the other peoples of the region, ... [Leosthenes] made his allies, bringing under his control (tên hêgemonian), by their own consent, the men whom Philip and Alexander gloried in controlling (hêgoumenoi) against their wish" (Hyperides, "Funeral Speech," Speeches, 6.13).

Imposed hegemony could equate to collective slavery: "after enslaving many great peoples which lay between the Thracians and the Egyptians they advanced the empire of the Scythians [tên hêgemonían tôn Skuthôn] on the one side as far as the ocean to the east, and on the other side to the Caspian Sea" (Diodorus, 2.43.5).

Hegemony could entail a more limited form of control over a subordinate state's exterior relations, allowing it to maintain internal self-rule. By the terms of a treaty of $314 \mathrm{BC}$ mediated by a Carthaginian, "of the Greek towns in Sicily, Heraclea, Selinus, and Himera were to be 
subject to the Carthaginians as they had been before, and all the others were to be autonomous [autonómous] under the hegemony [tên hêgemonian] of Syracuse" (Diodorus, 19.71.7).

Less often, but importantly, consensual hegemony could be an elective authority, a submission freely given, such as the Greeks gave to Athens on account of their respect for the justice of Aristides (Diodorus, 11.47.3), or the Sicilian Greeks to Syracuse on account of the fairness, humaneness, and mildness of Gelon (Diodorus, 11.67.2-4). Willing subordination produced allies, but in an alliance characterized by freedom without equality.

The style of hegemony could evolve. The Athenian ambassadors to Sparta (432 BC) admitted that they had become unpopular and obnoxious to their allies in their exercise of hegemony [têi hegemoniai], and had either to give it up, or to begin ruling the allies "with a strong hand." Motivated by pride, fear and self-interest, they chose to enforce their rule (Thucydides, 1.76.1-2).

Whether in the form of imposed slavery or voluntary submission, the common feature of all these styles of hegemony was obedience of the subaltern states or peoples to the commands of the hegemon, especially expressed by the hegemon's supreme command of joint military action.

\section{HEGEMONY AND EMPIRE}

Just as the English term "hegemony" derives from a Greek term, hêgemonia, whose earlier usage applied to a military command, so the English term "empire" derives from a Latin term, imperium, whose early usage also applied, very precisely, to military command. Following the displacement of Greek by Latin as the lingua franca of the learned of the West, and the later rise of vernaculars which quarried the established language of the learned to fit the circumstances needing to be described, "empire" entered the English vocabulary long before "hegemony" arrived. Do we need both these cognate terms? Have they usefully distinguishable meanings?

As there was great variation in the character of hegemonic relationships in classical Greece, there was also terminological ambivalence in the Greek description of hierarchical relationships. Like hêgemonía, the Greek term arkhê is also often translated as "empire" (or as "command"), but arkhê tends to denote a stronger form of subordination than hegemonía. Indeed, there was some attempt among the Greek historians to distinguish arkhê from hêgemonía, making arkhê mean rule of and by force, while hêgemonía should rest upon merit and upon a conditional consent to obey. But there was also a tendency to conflate the two; according to Wickersham, the arkhe--hêgemonía distinction, most clear-cut in Herodotus, is ambiguous in Thucydides and Xenophon, and absent in Ephorus (Wickersham 1994: 20-21, 45-47, 58-61, 82-84, 126-127; see also his General Index, s.v. hegemony). Similarly, when Strabo (trans. Jones, 6.4.2) speaks of the Romans by the time of Tiberius having subjected, fought down, acquired, conquered, subdued, subjugated, etc. many countries, while others are ruled by dependent kings, and even the very powerful Parthians give Rome hostages and send to Rome for kings, it seems fair to expect an analysis of an "empire"; but Strabo repeatedly speaks instead of Rome's "hegemony" and of her "allies" [summakhoi]. Is it then worthwhile for us to draw a sharp distinction between hêgemonía and arkhe, or between hegemony and empire?

I would argue for the value of retaining a distinction (at least as between the English terms). Underlying the question of the degree to which subaltern states consent to their status, that 
status itself implies that they retain a collective existence, a coherent identity - political, civic, cultural, territorial, demographic - which empire blurs, whether by the erasure or redrawing of traditional boundaries or by colonization and assimilation.

Even as we retain the distinction between hegemony and empire, we must accept that it cannot be very sharply drawn. There were many institutional transitions during the transformation of the Delian League into an Athenian Empire. Over time, entry into the alliance, and maintenance of membership, went from voluntary to coerced. Armed allies, providing autonomous forces to the alliance, became disarmed subjects paying tributes assessed by Athenian surveyors. Alliance decisions upon the employment of alliance funds and forces were replaced by unilateral Athenian decisions. Common funds once used for common military projects were diverted to provide benefits to the people and politicians of Athens. Eventually, Athens took hostages from suspect "allies," drove their citizens thought unreliable into exile, revised their constitutions, or settled Athenian overseers, garrisons and colonists upon them. (Diodorus 11.47, 70, 78, 83, 85; 12.5-7, 22, 27-28, 34, 37, 38, 40, 55, 46, 55, 72-73, 76; 14. 34, 36, 107; Plutarch, "Themistocles" 21.1; "Aristides" 24, 25; "Cimon" 11.1; "Pericles" 9, 12, 14, 16, 22-29, 34; Thucydides, 1.96-101, 105, 108, 111, 113-117; II 9, 63, 70, 102; III 2-6, 8-19, 25 28, 35-50). Considered together, all these measures constitute a repertoire of steps from hegemony to empire; yet there is no clear division point between the two very distinguishable conditions at either end of the multidimensional spectra.

With this caveat, let us proceed to examine the scope, motives, and natural history of Greek hegemony - i.e. hêgemonia and not arkhê, but hêgemonía that could always transform toward or into arkhe - as recorded and analyzed by the Greek historians.

\section{THE SCOPE OF HEGEMONY}

A hegemony could be held or sought with respect to a nation, e.g. the leadership of the Greeks, "tês tôn Hellênôn hêgemonías" (Diodorus, 4.61.9), or dominance over the Siceli, "tês tôn ... Sikelôn hêgemonías" (Diodorus, 12.29.2). Hegemony over a nation might be "homoethnic," whereby a tribe or other part of a nation took leadership of the whole, as the hegemony of the Trinacians over the Sicels, "tês tôn homoethnôn ... hêgemonías" (Diodorus, 12.29.2), or that of Saul the Benjamite "over the other tribes [tên tôn ethnôn hêgemonian] (Josephus, Antiquities 6.131)." Or the hegemony might be alloethnic, as of the Assyrians over many other nations (e.g. Diodorus, 2.2.3).

The venue of hegemony could be a territory: rule over Sicily, "tês katà Sikelian hêgemonías" (Diodorus, 13.22.5); over Boeotia, "tês hólês Boiôtías hêgoúmenoi" (Diodorus, 15.50.5); over Asia, "tên hêgemonían ... tês Asias" (Diodorus, 2.22.2).

A state could hold hegemony over the land, "tên ge katà gên hêgemonian" (Diodorus, 13.52.6) or the sea, "tês katà thálattan hêgemonías" (Diodorus, 11.50.3; cf. Polybius, 1.20.12), or both land and sea, "tên hêgemonían katà gên háma kaì katà thálattan" (Diodorus, 15.23.3-5).

There was hegemony over space, and hegemony over time: in $369 \mathrm{BC}$, the main issue of the Spartan-Athenian negotiations for an alliance against Thebes was whether to divide the land and sea commands [tês hegemonías], or to alternate them; a 5-day alternation in the command was the result (Xenophon, Hellenica 7.1.1-14). 
Several forms or aspects of hegemony might coexist. Athens in the time of Pericles possessed "tributes, armies, triremes, the islands, the sea, the vast power derived from Hellenes, vast also from Barbarians, and a supremacy [hêgemonían] that was securely hedged about with subject nations, royal friendships, and dynastic alliances" (Plutarch, "Pericles" 15.1).

Hegemony could be bounded, and several coexisting hegemons could then accord one another recognition. Thus the Persian king Artaxerxes II brokered a settlement, mainly between Sparta and Athens, in which "the Lacedaemonians and Athenians, who had constantly been rivals for the hegemony [tês hêgemonías], now yielded one to the other, the one being judged worthy to rule on land, the other on the sea" (Diodorus, 15.38.4).

Or the hegemony claimed, desired or acquired, could be boundless, even worldembracing: over "the whole [tôn holôn]," over "Earth [gê]"; over "everything" [hapantôn]." Cyaxares "became for the Medes the founder of their universal empire [tês tôn holôn hêgemonías]" (Diodorus, 2.32.3). Alexander "framed his hopes to gain world dominion" [tên tês oikoumenês hêgemonían] (Demades, "On the Twelve Years," 1.50). Before the battle of Cannae, Hannibal promised his troops that a Carthaginian victory over Rome would make them "leaders of the world" [hêgemones ... pantôn] (Polybius, 3.111.9). The Romans prepared Italy "as a centre from whence to enforce their universal dominion" [tên sumpasan hêgemonian] (Strabo, trans. Hamilton and Falconer, 6.4.2). At the battle of Zama (202 BC), the Roman commander Scipio promised his troops that, if they were to defeat Carthage, they and their country would have not only Africa, but the "command and sovereignty of the rest of the world [tês alless oikoumenês tên hêgemonian kai dunasteian]" (Polybius, 15.10.2). After the defeat of Carthage, "[t]here was great rejoicing at Rome that this mighty city, which had brought so many calamities upon them and had been the second or third in the leadership of the world [tôn epi tês gês deuteran ê tritên eichen hêgemonían], had been completely vanquished" (Appian, The Foreign Wars: The Punic Wars, 9.57). It was the (perceived) boundlessness of the resulting Roman empire, which brought "all the known parts of the world under one rule and dominion" (Polybius, 8.2.4), that animated Polybius to write the "general history of the world as a whole [tês katholikês kai koinês historias]," (8.2.11) so that how the Romans attained to "universal empire" [tês hapantôn hêgemonías] (8.2.6) might be learnt.

Today the subject of such boundless, all-embracing, universal hegemony would likely be styled "the world system."

\section{MOTIVES OF THE HEGEMONIZERS}

The Athenian ambassadors to Sparta, defending their acquisition of the Delian League, and its conversion from a voluntary to an enforced hegemony, gave as their motives honor (timê), fear (deos), and self-interest or profit (ophelia). They feared Persia, then Sparta, and sought a large naval following to protect themselves; they wished to be revered, respected, looked up to; and they enjoyed collecting tribute from their subject allies (Thucydides, 1.75.3-76.2). Sparta also turned hegemony into ophelia: "In Greece the Lacedaemonians, now [404 BC] that they had brought the Peloponnesian War to an end, held the supremacy [tên hêgemonian] by common acknowledgement both on land and on sea." They proceeded to make use of this supremacy to appoint Spartan governors for the cities, and to levy tribute upon the conquered peoples (Diodorus, 14.10.1-2). 
Power for its own sake, and for profit, mingled in the motives of hegemonizers. In 475 BC, the Spartan Assembly contemplated an attack upon Athens, with a war "to recover the leadership [tên hêgemonian], most present "believing that, if they could secure it, they would enjoy great wealth, Sparta in general would be made greater and more powerful, and the estates of its private citizens would receive a great increase of prosperity" (Diodorus 11.50.2-3).

If a hegemon led its followers to victory in war, it would gain glory (doxa). When the allied Greeks fought the army of Xerxes at Plataea (479 BC), the Spartans abjured the place opposite the Persians in the line of combat, and ordered the Athenians to take it up; and the Athenian Aristides urged his reluctant countrymen to accept this offer of "the leadership [tên hêgemonian] among the Hellenes on account of the "reputation" [tên doxan] that could thereby be gained (Plutarch, "Aristides," 16.2-3).

Achieving local hegemony could attract diplomatic conciliation, flattery, and offers of alliance from outside hegemons. By 380/79 BC, the Spartans "reached their greatest power, and won the overlordship of Greece on both land and sea [tês Helládos...tên hêgemonian katà gên háma kaì katà thálattan]. For the Thebans were secured by a garrison; the Corinthians and the Argives were safely humbled as a result of the previous wars; the Athenians had a bad reputation with the Greeks; the Lacedaemonians...were become an object of terror to all because of the strength of their following. Consequently the greatest rulers of that time, the Persian King and Dionysius the tyrant of Sicily, paid court to [etherapeuon] the Spartan overlordship [tên Spartiatôn hêgemonian] and sought alliance with them" (Diodorus, 15.23.3-5).

\section{LEVERAGING HEGEMONY}

Hegemony in one venue could be employed as a means to mobilize the capabilities and victories needed to achieve (or aspire to) a still more extensive hegemony. In their war against Xerxes (480-479 BC), the Athenians "increased their leadership [tên hêgemonian] to such a degree that, by their own resources and without the aid of Lacedaemonians or Peloponnesians, they overcame great Persian armaments both on land and on sea, and humbled the famed leadership [tên hêgemonian] of the Persians to such an extent that they forced them by a treaty to liberate all the cities of Asia" (Diodorus, 12.2.1-2). In this way the Athenians "won for themselves the leadership of Greece [tês Helládos tên hêgemonían]" (Diodorus, 13.25.2).

And again in $427 \mathrm{BC}$, "the Athenians, having won the supremacy of the sea [tên tês thaláttês hêgemonian] and accomplished great deeds, not only enjoyed the aid of many allies and possessed powerful armaments, but also had taken over a great sum of ready money, since they had transferred from Delos to Athens the funds of the confederacy of the Greeks, which amounted to more than ten thousand talents; they also enjoyed the services of great commanders who had stood the test of actual leadership; and by means of all these assets it was their hope not only to defeat the Lacedaemonians but also, after they had won the supremacy over all Greece [tês Helládos tên hêgemonían], to lay hands on Sicily" (Diodorus, 12.54.3).

In the 360s BC, Athens was sea-hegemon, Sparta was the declining land-hegemon, Thebes the ambitious and rising land-hegemonizer. Athens annoyed Thebes by assisting Sparta in its unsuccessful resistance to the growth of Theban land-power. In consequence, the Thebans decided in 364/3 BC that, having obtained the mastery on land, they should now "strive for the supremacy on the sea [tês katà thálattan hêgemonías]." They proceeded to order ships and 
dockyards and to create and send out to sea a force which overawed the Athenian admiral and "made the cities friendly to Thebes," i.e. gained island and coastal allies (Diodorus, 15.78.4 $79.2,88.4)$.

Without local hegemony to leverage, one's ability to acquire hegemony in a wider arena remained in doubt. The Athenian politician Nicias, objecting in $416 \mathrm{BC}$ to Athens' projected expedition against Syracuse, asked: "so long as they [the Athenians] were unable to secure their supremacy over the Greeks [tôn Hellênôn tên hêgemonian], how could they hope to subdue the greatest island in the inhabited world? [when] even the Carthaginians..., who possessed a most extensive empire [megistên hêgemonían] and had waged war many times to gain Sicily, had not been able to subdue the island..." (Diodorus, 12.83.6).

\section{HOW HEGEMONY WAS GAINED}

Hegemony was usually acquired by victorious war. In $455 \mathrm{BC}$, the cities of Sicily chose sides between Acragas and Syracuse and a general war ensued. The Syracusans won (Diodorus, 12.8). Thereupon, "the Greek cities of Sicily ... voluntarily conceded the hegemony [tên hêgemonian] to the Syracusans..." (Diodorus, 12.26.3). When in 404 BC Sparta finally crushed Athens to end the great Peloponnesian War, one of the terms of the peace required the Athenians to recognize the hegemony of the Lacadaemonians [Lakedaimonios hêgeomai khrêsthai] (Diodorus, 13.107.5). Rome's victory in the Mithridatic War "brought the greatest gains to the Romans, for it pushed the boundaries of their dominion [tên hêgemonian] from the setting of the sun to the river Euphrates" (Appian, The Foreign Wars: The Mithridatic Wars 17.119).

Establishing a friendly, or puppet, government after a victory or by intervening in civil strife was both a form of, and a means to, hegemony. Under the Peace of Antalcidas (387 BC), Sparta settled its dual war against Greeks and Persians by conceding dominance over the Greek cities in Asia to the Persian king, and independence to the other Greeks; but the Spartans soon "made up their minds to recover their supremacy [tên hêgemonian]" (Diodorus, 15.9.5), and to that end made use of factions of their friends in the Greek cities, including exiles whom they restored by force; "they at first enslaved the weaker cities, but afterward made war on and forced the more important cities to submit" (Diodorus, 15.5.3).

But the victory needed to be convincing to all. Upon defeating the Spartans at Leuctra (371 BC), the Thebans "claimed the hegemony of Greece [tês tôn Hellenôn hêgemonian]," but the Spartans refused to acknowledge defeat, and the Thebans lacked full faith in their victory (Polybius, 2.39.8), and indeed were never able to get the submission of Sparta, nor of Athens.

Good behavior by a powerful state could increase its influence. The transfer of Greek hegemony from Sparta to Athens in 477 BC was stimulated by the (deliberately) good behavior of the hegemonizer, by contrast with the bad behavior of the hegemon. "When [Aristides the Athenian] was sent out as general along with Cimon to prosecute the war, and saw that Pausanias and the other Spartan commanders were offensive and severe to the allies, he made his own intercourse with them gentle [praiôs] and humane [philanthrôpôs], and induced Cimon to be on easy terms [euarmoston] with them and to take an actual part in their campaigns, so that before the Lacedaemonians were aware, not by means of hoplites or ships or horsemen, but by tact [eugnômosunêi] and diplomacy he had stripped them of the leadership. For, well disposed as the Hellenes were toward the Athenians on account of the justice [dikaiosunên] of Aristides and the 
reasonableness [epieikeian] of Cimon, they were made to long for their supremacy still more by the rapacity of Pausanias and his severity" (Plutarch, "Aristides," 23.1-2). "Consequently, the allies no longer paid any heed to the commanders who were sent from Sparta, but in their admiration of Aristides they eagerly submitted to him in every matter." Thus Sparta lost "the supremacy at sea [tên katà thálattan hêgemonian]" to Athens without a fight (Diodorus, 11.44.5$6,11.46 .4-5)$. This episode was, however, unusual enough to inspire nostalgic reminiscence more than a century later; the Athenian orator Isocrates declared, "in former times....as the result of keeping our city in the path of justice and not coveting the possessions of others we were given the hegemony [tên hêgemonian] by the willing consent of the Hellenes" (Isocrates, "On the Peace," 30) .

Nicolaus of Syracuse made a similar nostalgic argument in 413 BC: "those who lay claim to leadership [tês hêgemonias], men of Syracuse, should not strive to make themselves strong in arms so much as they should show themselves reasonable [epieikeis, "fair," "mild"] in their character. The fact is that subject peoples bide their time against those who dominate them by fear and, because of their hatred, retaliate upon them, but they steadfastly cherish those who exercise their leadership humanely [philanthrôpôs, "benevolently"] and thereby always aid them in maintaining their supremacy [tên hêgemonían]." He reminded them that their historic "leadership in Sicily [tês katà Sikelian hêgemonías]" arose because the cities of Sicily had willingly put themselves under the authority of Gelon, drawn to him by his "fairness [epieikeia]" and his "sympathy for the unfortunate" (Diodorus, 13.21.8-13.22.5).

Xenophon's Socrates makes the same case, apparently on behalf both of individual fitness to command and state fitness to lead: those who are observed to behave justly, to abide by laws, are trusted, sought as friends and allies, and given leadership and command [hêgemonian] of garrisons and cities ("Memorabilia," 4.4.17). And in chapter V of his "Ways and Means," Xenophon addresses those who wanted to recover Athens' "ascendancy" [hêgemonian] by making an eloquent case for what might in a different context of today be called a "peaceful rise," or in Chinese Pinyin, Zhōngguó héping juéqǔ:

$[\mathrm{T}]$ here are some who wish the state to recover her ascendancy, and they may think that it is more likely to be won by war than by peace. Let such, in the first place, call to mind the Persian Wars. Was it by coercing the Greeks or by rendering services to them that we became leaders of the fleet and treasurers of the league funds? Further, after the state had been stripped of her empire through seeming to exercise her authority with excessive harshness, did not the islanders even then restore to us the presidency of the fleet by their own free will, when we refrained from acts of injustice? And again, did not the Thebans place themselves under the leadership of the Athenians in return for our good offices? Yet once again, it was not the effect of coercion on our part, but of generous treatment, that the Lacedaemonians permitted the Athenians to arrange the leadership as they chose. And now, owing to the confusion prevalent in Greece, an opportunity, I think, has fallen to the state to win back the Greeks without trouble, without danger, and without expense. For she has it in her power to try to reconcile the warring states, she has it in her power to compose the factions contending in their midst. And were it apparent that you are striving to make the Delphic shrine independent, as it used to be, not by joining in war, but by sending embassies up 
and down Greece, I for my part should not be in the least surprised if you found the Greeks all of one mind, banded together by oath and united in alliance against any that attempted to seize the shrine in the event of the Phocians abandoning it. Were you to show also that you are striving for peace in every land and on every sea, I do think that, next to the safety of their own country, all men would put the safety of Athens first in their prayers (Xenophon, 1925:"Ways and Means," 5.5$10)$.

Self-interested calculations could produce hegemonic subordination; powerful states could persuade weaker states to accept their hegemony by offering to defend their autonomy and their regimes, in return for submission. Referring to the Athenian-led "Delian League," to which Athens' allies contributed ships or money, Isocrates claimed that "our ancestors...acted for the advantage of the states which paid them tribute...not because we had so commanded, but because they themselves had so resolved at the very time when they conferred upon us the supremacy [ten hêgemonían] by sea.... [T] hey paid their quotas...to preserve their own democratic polity and their own freedom" (Isocrates, "Panathenaicus," 67-73).

Any state which could assemble armaments and money could enter the struggle for hegemony, sometimes simply by making a hegemonic claim, whose success however was by no means guaranteed. Gelon demanded that the Greek resistance to Xerxes willingly submit to Syracusan hegemony, or at least give him an equal share of the supreme command, on the grounds that he could provide the largest army and the largest navy of all the Greeks; but his demands were angrily rejected by the two next-most powerful states, Sparta and Athens (Herodotus, 7.157-162). In 370/69 BC, "Jason, tyrant of Pherae, because of his superior shrewdness as a general and his success in attracting many of his neighbors into an alliance, prevailed upon the Thessalians to lay claim to the supremacy in Greece; for this was a sort of prize open to those strong enough to contend for it." Sparta had just been defeated at Leuctra, "the Athenians laid claim to the mastery of the sea only," Thebes had only just freed herself from Sparta, and Argos was sunk in civil war; absent other claimants, Jason and Thessaly put themselves forward. Perhaps coincidentally, Jason was shortly thereafter assassinated, which terminated the Thessalian candidacy (Diodorus, 15.60.1-2).

Defeated hegemonizers could try again at once. 412 BC: "When the Athenians learned of the total destruction of their forces in Sicily, they were deeply distressed at the magnitude of the disaster. Yet they would not at all on that account abate their ardent aspiration for the supremacy [tês hêgemonias], but set about both constructing more ships and providing themselves with funds wherewith they might contend to the last hope for the primacy [tôn prôteiôn]" (Diodorus, 13.36.1). Or nostalgic ex-hegemons could seek a later, even much later, resurrection: when Alexander died in $323 \mathrm{BC}$, "the Athenians ventured to assert their liberty and to claim the leadership of the Greeks [tês koinês tôn Hellênôn hêgemonías]," since they had money and soldiers enough at hand to sustain the inevitable war (Diodorus, 18.9.1); and the Argives fighting Sparta at Mantinea $418 \mathrm{BC}$ were inspired to reclaim the "ancient hegemony" [palaías hêgemonias] they had possessed in the days of Agamemnon, 8 centuries or so before (Thucydides, 5.69.1). And in $279 \mathrm{BC}$, the Athenians were awarded command [hêgemonian] of the Greek forces that unsuccessfully resisted Brennus' invading Gauls at Thermopylae "because of their ancient reputation" (Pausanias, 10.20.5). 
Hegemony in a voluntary alliance could be rotated or divided. The anti-Spartan defensive-retaliatory Quadruple Alliance of 420 BC (Athens, Argos, Mantinea and Elis) promised the supreme command [tên hêgemonian] of any defensive coalition force to whichever allied state the Spartans might have attacked; but in retaliatory expeditions, the command [tês hêgemonias] was to be equally shared (Thucydides 5.47.7). Athens and Sparta rotated the command at set times in their alliance of 369 BC; the anti-Theban Peloponnesian League of 362 BC agreed that each people should hold the leadership [hêgemonias] of League forces within its own territory (Xenophon, Hellenica 7.1.14, 7.5.3).

\section{HOW HEGEMONY WAS KEPT}

Hegemony was subject to constant challenge, and might have to be maintained by constant war. Xerxes, preparing the Persians for their expedition against Athens, declared: "We have never yet remained at peace since...we won this our lordship [tên hêgemoniên] from the Medes" (Herodotus, 7.8A.1).

Hegemons feared the rise of new and independent powers, and obstructed it wherever they could. Preventive war was the usual means. In the late 6th or early 5th century BC, "since the city [of Heracleia, on the southern coast of western Sicily] grew rapidly, the Carthaginians, being jealous of it and also afraid that it would grow stronger than Carthage and take from the Phoenicians their sovereignty [tên hêgemonían], came up against it with a great army, took it by storm, and razed it to the ground" (Diodorus, 4.23.3). And in $468 \mathrm{BC}$, Argos, hegemonic in its vicinity, felt threatened by the independence of Mycenae. "The Mycenaeans, because of the ancient prestige of their country, would not be subservient to the Argives as the other cities of Argolis were, but they maintained an independent position and would take no orders from the Argives.... [T]he Argives were suspicious of the Mycenaeans, fearing lest, if they got any stronger, they might, on the strength of the ancient prestige of Mycenae, dispute the right of Argos to the leadership [tês hêgemonias]." Therefore, at a moment when the Mycenaeans were isolated, "the Argives, gathering a strong army from both Argos and the cities of their allies, marched against the Mycenaeans," defeated them in battle, besieged them, stormed the city, "sold the Mycenaeans into slavery, dedicated a tenth part of them to the god, and razed Mycenae" (Diodorus, 11.65.1-5).

440 BC:

The Syracusans had made subject to them all the cities of the Siceli with the exception of Trinaciê, and against it they decided to send an army; for they were deeply apprehensive lest the Trinacians should make a bid for the leadership of the Siceli, who were their kinsmen...[tês tôn homoethnôn Sikelôn hêgemonías]. Consequently the Syracusans marched against [Trinaciê] after having mustered all their own armaments and those of their allied states. The Trinacians were without allies, since all the other states were subject to the Syracusans, but they none the less offered a strong resistance. They held out valiantly against the perils they encountered and slew great numbers, and they all ended their lives fighting heroically.... And the Syracusans, after conquering in brilliant fashion men who had never before been subdued, sold the inhabitants into slavery and 
utterly destroyed the city, and the choicest of the booty they sent to Delphi as a thank-offering to the god (Diodorus, 12.29.1-4).

In 382/1 BC, "mindful of the danger that Thebes, if a suitable occasion arose, might claim leadership [tês hêgemonias] of Greece," the Lacedaemonians seized the Cadmeia, the citadel of Thebes, defeated Theban resistance, expelled some Thebans, terrorized the rest, and stationed a Spartan garrison there. "So the Thebans in this way lost their independence and were compelled to take orders from the Lacedaemonians" (Diodorus, 15.20.3).

The Thebans having remained outside some treaties made in 372/1 BC to divide hegemony in Greece between Athens and Sparta, the Spartans "decided to lead a large army against them as common enemies, for they cast an extremely jealous eye upon their increase of power, fearing lest with the leadership of all Boeotia [tês hólês Boiôtias hêgoúmenoi] they might break up the Spartan supremacy [tên hêgemonian tês Spártês], given a suitable opportunity" (Diodorus, 15.50.5).

Since hegemony often rested on the competence and charisma of a single person, a new ruler of a hegemonic state could expect to be challenged, and had to be prepared for a quick response. Upon the death of Philip II of Macedon, "the Athenians were not ready to concede the leading position among the Greeks [tês hêgemonias tôn Hellênôn]" to his son Alexander, and instigated a general revolt; but Alexander "brought everything into order impressively and swiftly. Some he won by persuasion and diplomacy, others he frightened into keeping the peace, but some had to be mastered by force and so reduced to submission" (Diodorus, 17.3.3-6).

The hegemon's claim to lead implied the obligation to lead, and to bear the costs of leadership, and was sustained thereby. Facing insuperable odds against the Persian invaders of Greece at Thermopylae (480 BC), the Spartan king Leonidas told his Lacedaemonians that "they must remain and not abandon the defence of the pass, for it was fitting that those who were the leaders of Hellas [toùs hêgouménous tês Helládos] should gladly die striving for the meed of honor"; the other Greeks he sent away (Diodorus, 11.9.1). The Spartan defenders of Thermopylae were slaughtered, but Sparta retained the supreme command of the allied Greek resistance to Persia.

\section{HOW HEGEMONY WAS LOST}

Thermopylae notwithstanding, hegemony unraveled fastest after military defeat,. In $446 \mathrm{BC}$, the Athenians were disastrously defeated at Coroneia in Boeotia, whereupon many cities revolted from them (Diodorus, 12.7.1). The Spartans were defeated by Thebes at Leuctra in 371/0 BC, and then again at Mantinea in $362 \mathrm{BC}$ were "utterly routed and hopelessly lost their supremacy [tên hêgemonían]" (Diodorus, 15.33.3; see also Polybius 9.8).

Subject allies were most likely to defect when the circumstances of the hegemon's defeat produced not admiration but contempt (kataphronêsis). In $412 \mathrm{BC}$, "after the Athenians had collapsed in Sicily, their supremacy [tên hêgemonian] was held in contempt [kataphronêthênai]; for immediately the peoples of Chios, Samos, Byzantium, and many of the allies revolted to the Lacedaemonians" (Diodorus, 13.34.1-2). Similarly, when in 396 BC the Carthaginians suffered a decisive defeat before Syracuse, and abandoned their Libyan subject allies, the Libyans, "who had long hated the oppressive rule of the Carthaginians [to baros tês tôn Karkhêdonion 
hêgemonias]... were inflamed against them. Consequently, being led on partly by anger [orgê] and partly by contempt [kataphronêsantes] for them because of the disaster they had suffered, they endeavored to assert their independence" (Diodorus, 14.77.1-2).

Not just military defeat, but any disaster which gave an impression of loss of power could evoke kataphronêsis and cause hegemonic relations to unravel. In 379/8 BC, "a plague broke out among the inhabitants of Carthage which was so violent and took off so many of the Carthaginians that they risked losing their commanding position [tên hêgemonian]. For the Libyans, undervaluing [kataphronêsantes] them, seceded, and the Sardinians, thinking they now had an opportunity to oppose the Carthaginians, revolted, and making common cause, attacked the Carthaginians" (Diodorus, 15.24.2).

Indeed, a hegemony based upon the prestige of a single leader could vanish at the moment of his demise. When Epaminondas died in victorious battle at Mantinea (362 BC), leaving no competent successor, he took with him the Theban "primacy of Hellas" [tên hêgemonían tês Helládos] and Theban hopes for command of the sea (Diodorus, 15.78.4-79.2, 15.88.4).

Just as hegemony was more durable when the subalterns perceived their hegemon as kindly (eunoïkos) and fair (dikaios), so the abuse of hegemonic power, or a sense of its abuse, could provoke revolt against it. "[T] he superiority of those who enjoy leadership [tôn hêgemónôn] is maintained by goodwill [eunoiai] and justice [dikaiosunêi], and is overthrown by acts of injustice [adikêmasi] and by the hatred [misei] of their subjects" (Diodorus, 14.2.1). Abuseengendered hatred of a hegemon could inspire its subject to transfer their submission to a rival. After leading the allied Greeks to victory at Plataea (479 BC), the Spartan commanders were "offensive" (epakhtheis) and "cruel" (khalepous) to their allies, showed "rapacity" (pleonexia), "severity" (barutês) and "angry harshness" (orgês ... kai trakheôs); in consequence, the Greek allies repudiated Spartan leadership [tên hêgemonían] (Plutarch, "Aristides" 23.1-5). In 477, the Athenians "succeeded...to the leadership [tên hêgemonian] over the allies, who freely chose them on account of their hatred [misos] of Pausanias," the violent and tyrannical Spartan commander (Thucydides, 1.96.1).

And after $386 \mathrm{BC}$, the Lacedaemonians once again proceeded to lose "the supremacy over the Greeks [tên tôn Hellênôn hêgemonían]" because they "used their allies roughly (biaiôs, "violently") and harshly (khalepôs), stirring up, besides, unjust and insolent (huperêphanous, "arrogant," "brutal") wars against the Greeks, and so it is quite to be understood that they lost their rule because of their own acts of folly. For the hatred of those they had wronged found in their disasters an opportunity to retaliate upon their aggressors..." (Diodorus, 15.1.2-4).

Greed (pleonexia) seemed to be the downfall of more than one hegemon of Greece. The accusation of rapacity laid against the Spartan commander Pausanias by the Greek allies in 478 $\mathrm{BC}$ was doubtless related to the war-taxes paid by the Greeks, who wanted to be assessed, but equably, and were satisfied by the tax-assessment of Aristides the Athenian. But as time passed, Athens trebled the assessments, spent them on its own spectacles, images and temples (Plutarch, "Aristides" 24.1-3), and in its turn earned the disaffection and rebellion of its subject-alliance.

Excess in general (hubris) could provoke rebellion. When the Romans conquered the Gallic Senones, expelled them from their territory, occupied the emptied land and colonized it with Romans, the Boian Gauls, who had been conquered and subjected, became convinced that 
Rome intended not just supremacy (hêgemonías), but ethnic cleansing - "expulsion and extermination" - and so revolted once again (Polybius 2.21.9).

Hegemonic subjects might also be provoked to revolt by the blandishments of an antihegemonic coalition. In $395 \mathrm{BC}$, all the other major powers of Greece - Thebes, Athens, Corinth and Argos - allied against Sparta. "It was their thought that, since the Lacedaemonians were hated by their allies because of their harsh (baros) rule, it would be an easy matter to overthrow their supremacy [tên hêgemonian], given that the strongest states were of one mind. First of all, they set up a common Council in Corinth to which they sent representatives to form plans, and worked out in common the arrangements for the war. Then they dispatched ambassadors to the cities and caused many allies of the Lacedaemonians to withdraw from them..." (Diodorus, 14.82.1-2).

Hegemony might even be voluntarily forsworn, though such abnegation was rare. After losing their command of the Greek alliance to Athens in $479 \mathrm{BC}$, the resentful Lacedaemonians at first threatened the Greeks who had fallen away from them with "appropriate punishment" and "considered making war upon the Athenians for the sake of regaining the command of the sea [tês katà thálattan hêgemonias]," but were influenced toward retrenchment by evidence that their commanders had been "corrupted by the great powers entrusted to them." Tired of the Persian war, fearing new corruption should they send out new commanders, uncertain that their interests required command of the sea, and persuaded that Athens was both capable and friendly, the Spartans decided that it was in Sparta's interest to "leave the Athenians with their leadership [tês hêgemonias]" (Diodorus, 11.50.1-6; Plutarch, "Aristides" 23.6; Thucydides, 1.95).

A fallen hegemony did not mean a reversion to general independence; successful rebels aspired to be masters. In $382 \mathrm{BC}$, Sparta installed a garrison in the Cadmeia, the citadel of Thebes, to return the latter to its previous subject-ally condition. The Thebans resisted, and expelled the garrison in 379 , defeating a relieving force as well. But that successful resistance to being subjugated led Thebes to entertain the greater ambition of subjugating others. By 375/4 BC, the Thebans, with good commanders and troops, were "elated in spirit and eager to dispute the supremacy on land [tês katà gên hêgemonías]" (Diodorus, 15.39.1). In 371/0 BC, the Thebans, led by Epaminondas, inflicted a severe defeat upon the Lacedaemonians at Leuctra (Diodorus, 15.55-56), then celebrated the role-reversal by invading and devastating Laconia (Diodorus, 15.63-66). Thus the Thebans, "who for many generations had been subjects of their superiors [the Spartans], when they defeated them to everyone's surprise, became supreme [hêgemónes] among the Greeks" (Diodorus, 15.1.5 - the "Theban hegemony" is however not generally accepted, though the Theban desire to possess such hegemony is conceded).

\section{HEGEMONY AND IDEOLOGY}

While most of the propaganda disseminated during hegemonic struggles appealed to the freedom and pride of the states, the long struggle between Sparta and Athens also involved a conflict of political ideology with respect to regime type, and their conflicting ideologies attracted appropriate support. "[T]he foremost Corcyraeans, who desired the oligarchy, favoured the cause of the Lacedaemonians, whereas the masses which favoured the democracy were eager to ally themselves with the Athenians. For the peoples who were struggling for leadership [tês hêgemonías] in Greece were devoted to opposing principles; the Lacedaemonians, for example, 
made it their policy to put the control of government in the hands of the leading citizens of their allied states, whereas the Athenians regularly established democracies in their cities" (Diodorus, 13.48.4) . "[E]ach of the two states that in the past held the leadership [hêgemoniai] of Greece took as a pattern the form of government that existed among themselves and set up in the one case democracies and in the other oligarchies in the cities, not considering the interest of the cities but their own advantage" (Aristotle, Politics 4.1296a).

\section{SUBHEGEMONY}

One could seek a delegated or local hegemony under the hegemony of an overlord. In $367 \mathrm{BC}$, the Thebans, "who were continually planning how they might obtain the leadership [tên hêgemonían] of Greece," hit on a means to use their past services to the Persians as a means to obtain Persian endorsement of their plan to get control of a Greek alliance to constrain Sparta and Athens; but both the wealth and the fighting capacity of the Persians were judged inadequate to convince the Greeks of the need to bend to Persian directives with Theban enforcers (Xenophon, Hellenica 7.1.33-40).

Other applications for subhegemony were more successful. In 457 BC, Sparta and Athens were at war. The Thebans, having lost their ancient influence and reputation, were held in disdain by their Boeotian neighbors, who no longer paid any attention to them; Thebes "asked the Lacedaemonians to aid them in winning for their city the hegemony [tên hêgemonían] over all Boeotia," in return for which the Thebans would attack the Athenians; and indeed the Lacedaemonians assented, and "compelled the cities of Boeotia to subject themselves to the Thebans" (Diodorus, 11.81.2-3). In 387 BC, it was Sparta's turn to apply for subhegemon status: the Spartans, questing for "supremacy in Greece [tên tôn Hellênôn hêgemonían]" needed Persian money to finance their seizure of power, and for that money negotiated and enforced the Peace of Antalcidas, under which the Greek cities of Asia were abandoned to Persian rule, while the leagues led by Thebes and Athens were dissolved, and Sparta got a free hand to order affairs in Greece (Polybius, 6.49-50).

\section{ROOTS OF HEGEMONY}

Of all the classical writers, it is Strabo, writing at the height of Roman expansion under Augustus and Tiberius, who gives greatest attention to the underlying factors which advantaged some states in the competition for hegemony. Strabo attributes the Spartan hegemony to their (ultramilitaristic) Lycurgan constitution: "after they had intrusted to Lycurgus the formation of a political constitution, they acquired such a superiority over the other Greeks, that they alone obtained the sovereignty both by sea and land, and continued to be the chiefs of the Greeks, till the Thebans, and soon afterwards the Macedonians, deprived them of this ascendency [tên hêgemonían]" (Geography, trans. Hamilton and Falconer, 8.5.5). A warlike culture was also serviceable to non-Greek hegemonizers: referring to the Arsacids of Parthia, and their governance of a large country and many nations, Strabo declares that the magnitude of their domain "is to be attributed to their mode of life and manners, which have indeed much of the barbarous and 
Scythian character, but are very well adapted for establishing dominion [hêgemonían], and for insuring success in war" (Geography, trans. Hamilton and Falconer, 11.9.2).

Militarism alone was not enough, however; there was a place for diplomacy as well. Thebes' sudden loss of hegemonic prospects after the death of Epaminondas at Mantinea in 362 $\mathrm{BC}$ inspired Ephorus to reflect upon the requisites of durable hegemony, some of which Thebes lacked. As cited by Strabo, Ephorus praises Thebes' home region, Boeotia, for its fertility and its good strategic position, and judges that:

[I]t has natural advantages for obtaining supreme command [hêgemonian], but... from want of careful education and learning [paideiai], even those who were from time to time at the head of affairs did not long maintain the ascendency they had acquired, as appears from the example of Epaminondas; at his death the Thebans immediately lost the supremacy they had just acquired. This is to be attributed, says Ephorus, to their neglect of learning [logôn], and of intercourse [homilias] with mankind, and to their exclusive cultivation of military virtues. It must be added also, that learning and knowledge are peculiarly useful in dealing with Greeks, but in the case of Barbarians, force is preferable to reason. In fact the Romans in early times, when carrying on war with savage nations, did not require such accomplishments, but from the time that they began to be concerned in transactions with more civilized people, they applied themselves to learning, and so established universal dominion (Strabo, Geography, trans. Hamilton and Falconer, 9.2.2).

The hegemony of Rome being to Strabo the most impressive, he discussed its sources at some length, and gave particular emphasis to the local geopolitics and geoculture of Italy:

And while I have already mentioned many things which have caused the Romans at the present time to be exalted to so great a height, I shall now indicate the most important things. One is, that, like an island, Italy is securely guarded by the seas on all sides, except in a few regions, and even these are fortified by mountains that are hardly passable. A second is that along most of its coast it is harborless and that the harbors it does have are large and admirable. The former is useful in meeting attacks from the outside, while the latter is helpful in making counterattacks and in promoting an abundant commerce. A third is that it is characterized by many differences of air and temperature, on which depend the greater variation, whether for better or for worse, in animals, plants, and, in short, everything that is useful for the support of life. Its length extends from north to south, generally speaking, and Sicily counts as an addition to its length, already so great. Now mild temperature and harsh temperature of the air are judged by heat, cold, and their intermediates; and so from this it necessarily follows that what is now Italy, situated as it is between the two extremes and extending to such a length, shares very largely in the temperate zone and in a very large number of ways. And the following is still another advantage which has fallen to the lot of Italy; since the Apennine Mountains extend through the whole of its length and leave on both sides plains and hills which bear fine fruits, there is no 
part of it which does not enjoy the blessings of both mountain and plain. And add also to this the size and number of its rivers and its lakes, and, besides these, the fountains of water, both hot and cold, which in many places nature has provided as an aid to health, and then again its good supply of mines of all sorts. Neither can one worthily describe Italy's abundant supply of fuel, and of food both for men and beast, and the excellence of its fruits. Further, since it lies intermediate between the largest races [i.e. Iberians, Celts and Germans] on the one hand, and Greece and the best parts of Libya [i.e. modern Tunisia] on the other, it not only is naturally well-suited to hegemony [hêgemonian], because it surpasses the countries that surround it both in the valor of its people and in size, but also can easily avail itself of their services, because it is close to them (Geography, trans. Jones, 6.4.1).

Polybius attempts to move toward a comparative study of hegemonies and their several roots. In his view, the hegemonies of Persia, Sparta and Macedon were so noticeably inferior to that of Rome, who subjected "nearly the whole of the world [skhedon de pasan ...tên oikoumenên]" that it was important to learn how Rome succeeded where others failed (Histories, 1.2.7). Polybius proposed that it was the Romans' "schooling themselves in ...vast and perilous enterprises" - long, unbroken wars involving unprecedentedly large forces - that gave them both the ambition and the capacity to achieve "universal dominion [têi tôn holôn hêgemonia]" (Histories, 1.63.9), while the ability to mobilize such forces was a consequence of their political institutions (1.64.1-2) and their abundant revenues (6.50.6), as well as of customs and institutions which assigned public glory to the heroic dead (6.51-56).

\section{CONCEIVING HEGEMONY, CLASSICAL AND MODERN}

These episodes in classical history, as narrated by the inventors of the concept of hegemony, seem to provide a reasonably consistent theory of what hegemony is, and how and by whom it is, or may be, desired, sought, acquired, kept, shared, passed onward, and lost.

We can derive some useful shades of meaning of "hegemony" from the need felt by the translators of classics to translate hêgemonia differently in different contexts, as power, leadership, command, supremacy, dominance, dominion, lordship, sovereignty, and empire. But the historically most central meaning, and the most useful for both comparative and contemporary usage, appears to be command, especially supreme command.

Hegemony is clearly a political, or politico-military relationship, not an economic nor a cultural one, though wealth and culture may be resources that enable hegemony. More particularly it is a power relationship of great inequality, most particularly one not of unbalanced capabilities only, but of asymmetric influence, influence consciously intended, consciously exerted and consciously accepted.

There is a wide range of bases of hegemonic influence. Some sources of politico-military hegemony might reasonably be called "cultural" or "moral" - this when willing compliance is awarded because of admiration and a good reputation. Some sources of hegemony might be called, broadly or narrowly, "economic" - broadly when they involve an calculation of self-interest and an exchange of value for value, narrowly when they entail money going one way (subsidy from the 
hegemon, or tribute to the hegemon), in return for the use or the availability of force (in the hegemon's enterprises, or for the defense of the subject ally). And some sources of hegemony seem quite narrowly politico-military: the threat of force and the use of force by the hegemon to compel or reward alliance and allied compliance; the hegemon's intervention in the ally's constitution, so as to empower a faction preferred by or loyal to the hegemon.

Classical hegemony entails conspicuous agency; classical hegemons consciously contemplate and intend hegemony. Hegemons and hegemonizers want hegemony for its own sake, for security against fear, and for the wealth, glory, respect, and flattery it can bring in its train.

Hegemony may be sought or exercised over nations, over an alliance, over territories or regions, over the land or the sea, or over tôn holon, "the whole." "Territories" turn out to be the states and nations thereon, "land" and "sea" are actually "the mainland states" and "the island states," and tôn holon is the world system, the system of states. Thus the targets or subjects of hegemony are also conscious actors.

A bilateral hegemonic relationship between states would involve a hegemon that led, and was followed by, some less powerful state - call it an ally, an auxiliary, a subject ally, a subaltern, a protectorate - over which it exercised its influence through some combination of charisma, morality, defense, extortion, assistance, deception, threat, intervention, or coercion. A key locus of the hegemonic relationship would be joint warfare, in which the hegemon would take the lead and the joint command, whosever interests were at stake.

The hegemon of a region or of a multilateral alliance would procure followership in the same ways as the hegemon in a bilateral relationship, and additionally by leading the combined force of the alliance against its own rebellious or recalcitrant members, as well as against external enemies. Either a set of bilateral arrangements or a single multilateral structure (or even both) could institutionalize a regional hegemony: i.e. the hegemon's several allies might or might not also be mutually allied; they could even be quite hostile to one another;

Systemwide hegemony is more than power unipolarity, but less than universal empire. On the one hand, a unipolar capability distribution would not be a hegemony until accompanied by a unipolar influence structure of actual leadership and followership; on the other hand, a systemwide hegemony would become a systemwide empire when the subject peoples and states were remixed and reordered as provinces, nomes, satrapies, prefectures - as the internal segments of a new large state. A world system with a hegemon would have a unipolar influence structure, perhaps a collection of bilateral connections to the hegemon, perhaps a general confederation with the hegemon its permanent president, perhaps some more mixed and complex structure. The hegemon of a world system would exercise its influence similarly to a regional/alliance hegemon; but as all states in the system would be under its hegemony, there would be no external enemies to combine against, but only the occasional rebellious confederate ally to be put down.

We can learn much from study of the most frequent hegemonies (bilateral, regional, and alliance hegemonies) that can be applied to the study of the much rarer civilization-wide, systemwide hegemony. But for purposes of theoretical development, and even of policy discussions concerning the power structure of the current global civilization/world system, I would judge that the concept of greatest interest, and the topic most in need of comparative-historical study, is systemwide hegemony, "hê tôn holôn hêgemonía."

Those who revived the classical term for modern application found ample scope for its employment in the context of the $19^{\text {th }}$ century. That much of the phenomenology of "classical" hegemony is evident in $20^{\text {th }}$ century world politics, and in the contemporary world, probably 
requires no extensive proof. Perhaps the insights of the classical writers can still be of service to analysis and policy, to scholarship and to statecraft.

\section{REFERENCES}

Allgemeine deutsche Real-Encyklopaedie fuer die gebildeten Staende. 1824. Leipzig: Brockhaus.

Appian. 1899a. The Civil Wars, ed. Horace White. London: Macmillan. 1899b. The Foreign Wars: The Mithridatic Wars, ed. Horace White. New York: Macmillan.

Aristotle. 1944. Politics. Vol. 21 of Aristotle in 23 Volumes, translated by H. Rackham. Cambridge, MA: Harvard University Press.

Demades. 1941-1954. "On the Twelve Years," trans. J. O. Burtt. Minor Attic Orators in two volumes. Cambridge, MA; Harvard University Press.

Diodorus Siculus. 1933-1967. Library. (Diodorus of Sicily in Twelve Volumes.) Vols. 1-6 trans. C.H. Oldfather; vol. 7 trans. Charles L. Sherman; vol. 8 trans. C. Bradford Welles; vols. 9-10 trans. Russel M. Geer; vols. 11-12 trans. Francis R. Walton. Cambridge, MA: Harvard University Press.

Groen van Prinsterer, Guilielmus [Guillaume]. 1821. De principatu (hegemonia) Atheniensium. Responsio ad quaestionem literariam. Annales Academiae Lugduno-Batavae. Lugduni Batavorum: S. et J. Luchtmans.

Herodotus. 1920-1921. Herodotus, with an English translation by A.D. Godley. 4vols. Cambridge, MA: Harvard University Press.

Homer. Homer's Iliads. 1844. Translated out of Greek by Thomas Hobbes of Malmesbury. The English Works of Thomas Hobbes, ed. Sir William Molesworth. London: John Bohn.

. 1924. The Iliad, with an English translation by A.T. Murray. 2 vols. Cambridge, MA: Harvard University Press.

. The Iliad of Homer. 1942. Translated by Samuel Butler, edited by Louise R. Loomis. New York: Walter J. Black.

. 1950. The Iliad of Homer. Translated by Andrew Lang, Walter Leaf and Ernest Meyers. New York: The Modern Library.

. 1992. The Iliad. Translated by Robert Fitzgerald. New York: Knopf. . 1997. Iliad. Translated by Stanley Lombardo. Indianapolis: Hackett.

. 2002. The Iliad: a new translation by Ian Johnston. http://www.mala.bc.ca/ johnstoi/homer/ iliad title.htm

. Iliad. 2007. Greek text citations from Perseus Digital Library Project, ed. Gregory R. Crane. Tufts University. Accessed July 2007. <http://www.perseus.tufts.edu>.

Hyperides. 1941-1954. "Funeral Speech," trans. J.O. Burtt. Minor Attic Orators in two volumes. Cambridge, MA: Harvard University Press.

Isocrates. 1929a. "On the Peace." Isocrates ... in three volumes, trans. George Norlin. Vol. 2. New York: Putnam.

1929b. "Panathenaicus." Isocrates ... in three volumes, trans. George Norlin. Vol. 2. New York: Putnam. 
Josephus, Flavius. 1895. Antiquities of the Jews. The Works of Flavius Josephus, trans. William Whiston. Auburn and Buffalo: John E. Beardsley.

Liddell, Henry George, and Robert Scott. 1889. An Intermediate Greek-English Lexicon. Oxford: Clarendon Press. . 1968. A Greek-English Lexicon. Revised ed. with supplement. Oxford: Clarendon Press.

Manso, Johann Caspar Friedrich. 1800-1805. Sparta: Ein Versuch zur Aufklaerung der Geschichte und Verfassung dieses Staates. 3 vols., Leipzig: In der Dyckischen Buchhandlung.

The Oxford English Dictionary. 1933. Oxford: Clarendon Press.

Pausanias. 1918. Description of Greece, trans. W.H.S. Jones and H.A. Ormerod. 4 vols., Cambridge, MA: Harvard University Press.

Pierer, H.A. [Heinrich August], ed. 1840-1846. Universal-lexikon der gegenwart und vergangenheit; oder, Neustes encyclopaedisches woerterbuch der wissenschaften, kuenste und gewerbe, bearb. von mehr als 220 gelehrten. 34 vols. in $17.3^{\text {rd }}$ ed. Altenburgh, H.A. Pierer.

Polybius. 1922-1927. The Histories, trans. W.R. Paton. Cambridge, MA: Harvard University Press.

Plutarch. 1914-1926. Plutarch's Lives, trans. Bernadotte Perrin. Cambridge, MA: Harvard University Press.

Thucydides. 1930-1935. History of the Peloponnesian War, trans. Charles Forster Smith. London: William Heinemann.

Strabo. 1903. The Geography of Strabo, ed. H.C. Hamilton and W. Falconer. 3 vols. London. George Bell \& Sons.

1924. The Geography of Strabo, ed. H.L. Jones. Cambridge, MA: Harvard University Press.

Wickersham, John. 1994. Hegemony and Greek Historians. Lanham, MD: Rowman and Littlefield.

Xenophon. 1921. Hellenica, Books V-VII, trans. Carleton L. Brownson. Cambridge, MA: Harvard University Press.

1923. "Memorabilia." Memorabilia and Oeconomicus, trans. E.C. Marchant. Cambridge, MA: Harvard University Press.

. 1925. "Ways and Means." Scripta Minora, trans. E.C. Marchant. Cambridge, MA: Harvard University Press. 